\title{
Isolation and screening of cellulase producing bacteria isolated from soil
} S.H.Abdel-Aziz ${ }^{1}$, A.M.Ibrahim ${ }^{2}$, A.AGuirgis ${ }^{2}$, G.E.Dawwam ${ }^{1}$ and Z.E.Elsababty ${ }^{1}$

${ }^{1}$ Botany and Microbiology, Dept., Faculty of Science, Benha Univ., Benha, Egypt

${ }^{2}$ Microbial Biotechnology, Dept., Genetic Engineering and Biotechnology Research Institute (GEBRI), University of

Sadat City, Menoufia, Egypt

E-mail:ghada.ibrahem@fsc.bu.edu.eg

\begin{abstract}
Cellulases are enzymes produced by many organisms and cellulose hydrolysis. They are well-known for their widely distributed industrial and medical uses. In this work, 84 bacterial strains were recovered from agar plates and 24 demonstrated hydrolyzing areas from carboxymethyl cellulose-containing agar dishes following Congo-Red staining. Among the 24 strains, three isolates Z7, Z9 and Z63 have shown increased activity of carboxymethyl cellulase (CMCase). It was shown that the three strains, Bacillus and Klebsiella, belonged to 2 separate genera. The isolates have been morphologically, physiologically, biochemically determined and validated by their 16S rRNA gene sequence. The 16S rRNA sequence of Z7, Z9 and Z63 has been submitted with GenBank under the accession codes (KT693283, KT693282 and KT693284). The sequences have been identified as Bacillus cereus strain Z7, Bacillus licheniformis strain Z9 and Klebsiella oxytoca strain Z63. This study gave appropriate information on the variety of rhizospheric isolated cellulose-degrading bacteria.
\end{abstract}

Key words: Cellulase producing bacteria, Cellulase, screening, soil.

\section{Introduction}

Cellulose is a polymer of D-glucose residues joined by $\beta-1$. Cellulose is nature's most abundant carbon dioxide since it is the fundamental structural substance of the cell wall of the plant [21]. The development of technologies for the efficient treatment and use of cellulose waste such as low-cost carbon sources is therefore of major commercial significance. The enzyme system termed cellulases degrades cellulose. Cellulase is a complicated enzyme, requiring endoglucanase, exoglucanase, and $\beta$-glucosidase to work synergetically[18]. This enzyme is generated by several microbes, mostly bacteria and fungus. By contrast, the rate of development and resilience of bacterial species to harsh conditions is higher[12][30]. Most mushrooms can breakdown amorphous and crystalline cellulose but most bacterial strains only hydrolyse amorphous cellulose efficiently (CMC, carboxymethylcellulose). Many of the reports of cellulases isolated from various bacteria have been obtained, such as Thermomonospora sp [6], YJ5 [29] Cellulomonas sp., Melanocarpus sp. MTCC 3922[9], Fluorescens Pseudomonas [2], Horikoshi Pyrococcus [8], Bacillus sp. [1], [3] [6],[10]. Microbial cellulases are used in numerous sectors, notably for the textile, pulp, paper, food and detergent sectors, as well as for the treatment of cellulosic waste[25],[11]. In hydrolyses of renewable lignocellulosic waste materials, cellulases also play an essential role in the creation of biofuels such bioethanol[24].

Enzyme production is regulated in microorganisms and these controls may be modified to boost their productivity. Induction of cellulase depends on a complicated interaction that involves a range of parameters, such as inoculum size, $\mathrm{pH}$, temperature, induction presence, medium additives, aeration, period of development and so forth[20]. The cost-effective manufacturing and discovery of novel cellulase sources is continuously needed. The present investigation has thus been carried out to identify possible soil cellulose degrading bacteria. Selected bacterial isolates have been tested using CMCase (carboxymethyl cellulase) for the endoglucanase enzyme activity.

\section{Materials and methods Sample Collection}

Soil samples were collected from farm fields at Menoufia governorate $\quad\left(30^{\circ} 35^{\prime} 50.09^{\prime \prime} \mathrm{N}\right.$, $\left.30^{\circ} 59^{\prime} 15.48 " \mathrm{E}\right)$, Egypt, from 5-10 cm depth in sterile plastic bag (Nikky et al.,2019). The samples were kept at $4^{\circ} \mathrm{C}$ up to further processing.

Isolation and screening of cellulase producing bacteria

Soil suspension was prepared by suspending $1 \mathrm{~g}$ soil into $9.0 \mathrm{~mL}$ sterile distilled water to set up 10 -fold serial dilutions (Patagundi et al., 2014; Saini et al., 2012). Soil suspension $(0.1 \mathrm{~mL})$ was spread on to nutrient agar plates amended with $1 \%(\mathrm{w} / \mathrm{v}) \mathrm{CMC}$ and incubated overnight at $37^{\circ} \mathrm{C}$.

After incubation period, selected bacterial colonies were again streaked on agar plates containing CMC (carboxymethyl cellulose) $10 \mathrm{~g}$; peptone $5 \mathrm{~g}$; yeast extract $5 \mathrm{~g}$; $\mathrm{NaCl} 5 \mathrm{~g}, \mathrm{KH} 2 \mathrm{PO} 41 \mathrm{~g}$; and $2.0 \%$ agar $(\mathrm{w} / \mathrm{v})$, then $\mathrm{pH}$ was adjusted to 7.2 . The plates were incubated for $48 \mathrm{~h}$ at $37^{\circ} \mathrm{C}$. After incubation period the plates were stained with $1 \%$ Congo red solution at room temperature for $15 \mathrm{~min}$ and de-stained for $20 \mathrm{~min}$ using $1 \mathrm{M} \mathrm{NaCl}$. Cellulose degrading bacterial isolates were selected by the formation of clear zones around colonies through the Congo red overlay method (Teather and Wood, 1982). The most cellulolytic bacterial colonies were sub-cultured and purified on nutrient agar. The bacterial strains were stored on nutrient agar at $4^{\circ} \mathrm{C}$.

Identification of cellulolytic bacteria by morphological and biochemical characterization

For the identification of the most potent three bacterial strains, Z7, Z9 and Z63, cultural 
characteristics, morphological characteristics, and biochemical tests were done according to methods as given in Bergey's Manual of Systematic Bacteriology [4]. The parameters investigated included Gelatin hydrolysis test, Casein hydrolysis test, Starch hydrolysis test, Urease Activity, Lipase Activity, Xylanase Activity, Catalase Activity, Methyl red reaction, and Vogues-Proskauer reaction. The various types of media was prepared in sterile distilled water and $\mathrm{pH}$ was adjusted accordingly.

Scanning electron microscopic (SEM) study of the bacteria

The morphology of the isolates was observed using a Scanning electron microscope (SEM) (Model JSM-5500 LV JEOL "JAPAN") at the Regional Center for Mycology and Biotechnology, Al-Azahr University.

\section{Molecular identification of bacterial isolates}

Extraction of DNA and molecular phylogenetic analyses using 16S rRNA gene Sequence

The genomic DNA for the three most cellulolytic activity bacterial strains Z7, Z9 and Z63 was extracted from the cells grown on LB broth and purified using the protocol for bacterial DNA extraction in the GspinTM Total Extraction kits according to the supplier's recommendations.

The resulting 16S rRNA genes of the new isolates were amplified by Thermocycler (Biometra thermocycler, Germany) using the universal primers 27F (5'-AGAGTTTGATCCTGGCTCAG-3') and1492R (5'-GGTTACCTTGTTACGACTT-3') as described by Pandey et al. (2002). The amplified 16S rDNA PCR product was sequenced using automated ABI 3730xl sequencer at (Macrogen Inc., South Korea). The PCR amplification condition is consisted of an initial denaturation at $94^{\circ} \mathrm{C}$ for $2 \mathrm{~min}$, followed by 35 cycles $\left(94^{\circ} \mathrm{C}\right.$ denaturation for $30 \mathrm{sec}, 55^{\circ} \mathrm{C}$ annealing for $30 \mathrm{sec}, 72^{\circ} \mathrm{C}$ extension for one min) and final elongation at $72^{\circ} \mathrm{C}$ for five min.

The Sequence Similarity Search was done for the 16S rDNA sequence using online search tool called BLAST (http://www.ncbi.nlm.nih.gov/blast/).The unknown organism was identified using the maximum aligned sequence through BLAST search.

\section{Results and discussion \\ Isolation, screening and identification of cellulase producing bacteria}

In total, 84 bacterial isolates were initially isolated from serially diluted soil samples. Twenty-four isolates revealed halo zones on the LB agar plates containing $1 \% \mathrm{CMC}$ after staining with $1 \%$ Congo red solution. Of these, three bacterial isolates (Z7, Z9 and Z63) were selected on the basis of halo zone diameter giving (2, 1.8 and $1.6 \mathrm{~cm})$ respectively (Fig. 1). The use of Bacillus sp for CMC production has been reported by various workers [26] , [13]. According to the morphological and biochemical tests, the isolated strains were identified as Bacillus and Klebsiella (methods in general and molecular bacteriology).

The biochemical characterizations of the isolated strains (Z7, Z9and Z63) are presented in Table 1. A microscopic examination revealed that the isolated strain Z7 and Z9 was rod shaped and found to be gram positive whereas Z63 strain was short rod in shape and found to be gram negative.

\section{Scan Electron Micrograph (SEM)}

The most potent cellulolytic isolated bacteria were scanned by electron microscope (JSM-5500 LV JEOL "JAPAN") and appeared rod- shaped as shown in fig. (2).

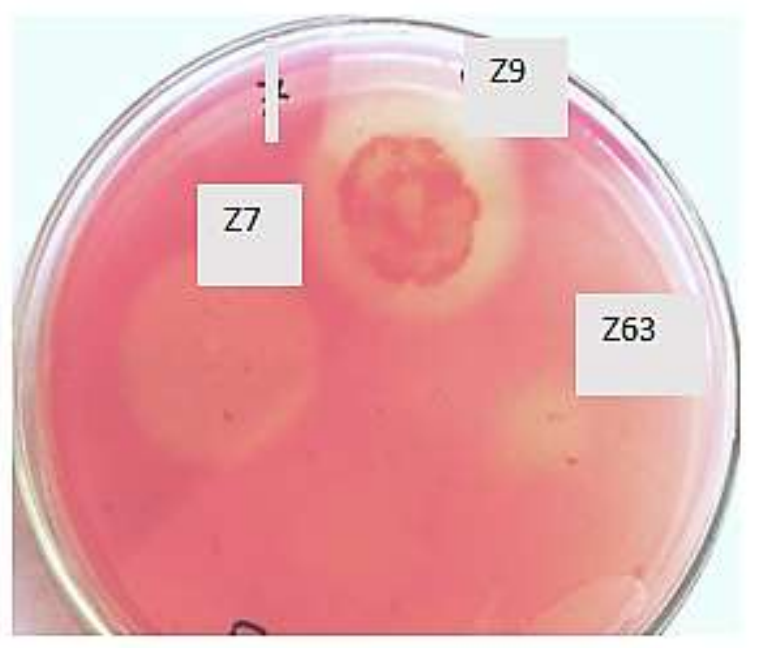

Fig. (1) Showing the most three potent cellulolytic strains Z7, Z9 and Z63 isolated from soil samples. 


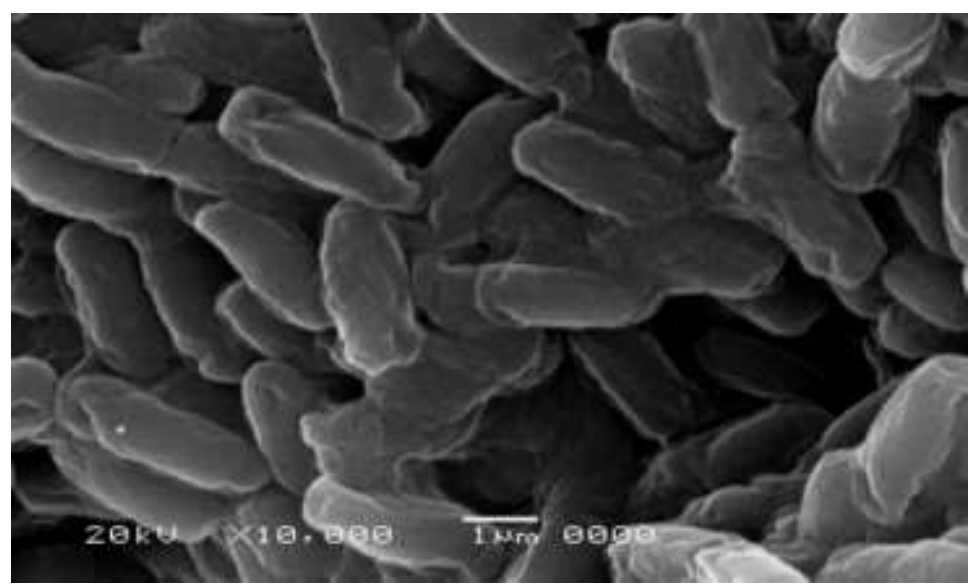

Bacillus cereus strain $-\mathbf{Z 7}$

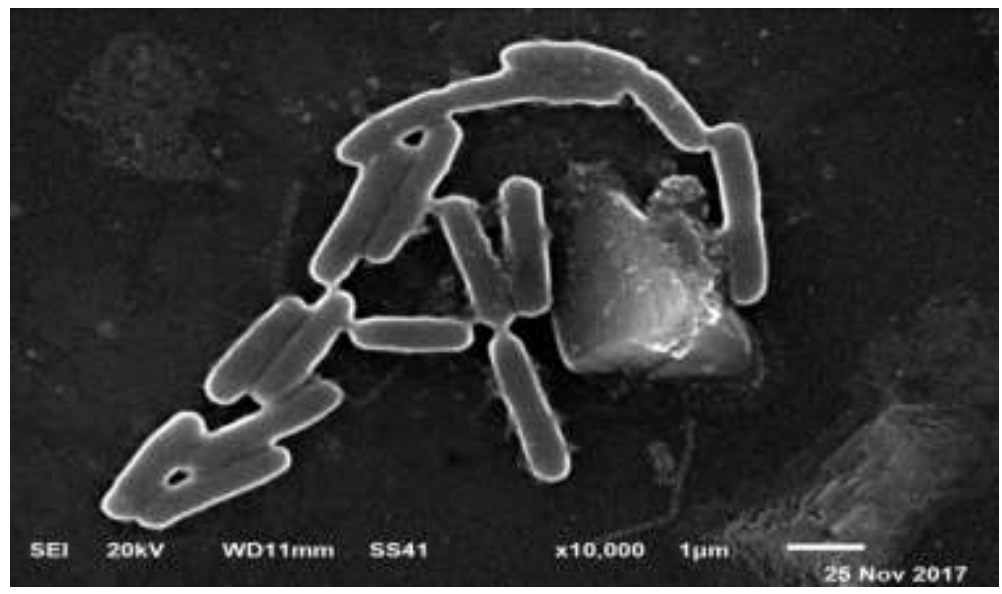

Bacillus licheniformis strain- Z9

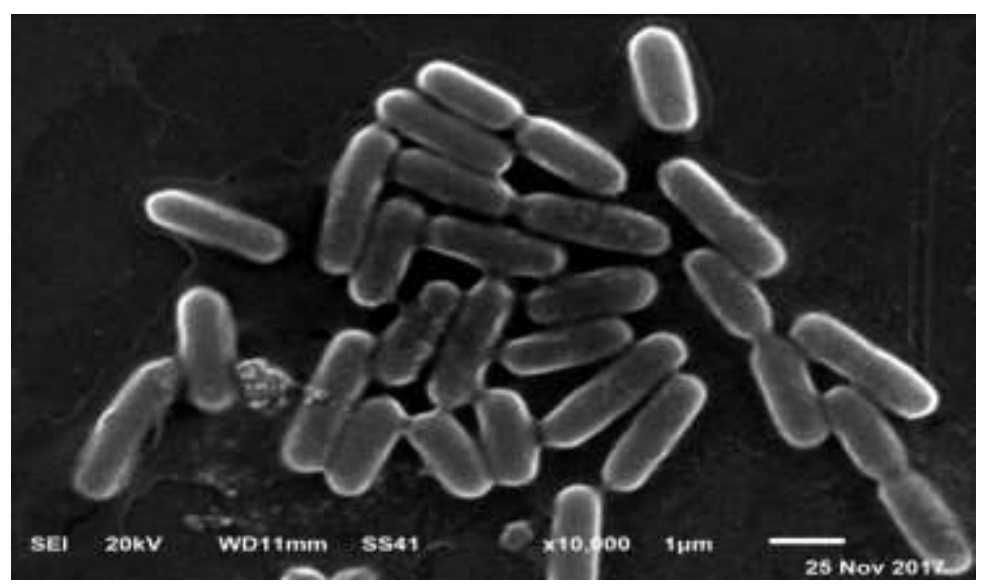

Klebsiella oxytoca strain- Z63

Fig. (2) Scan Electron Micrograph of the most cellulolytic bacterial isolates Z7, Z9 and Z63.

Morphological, physiological and biochemical characteristics of the three chosen bacterial isolates

The three most potent cellulosic were reference data were got the genus Bacillus and characterized morphologically, physiologically and Klebsiella (methods in general and molecular biochemically. They are listed in table (1) from the bacteriology). 
Table (1) Morphological and biochemical characteristics of the three chosen bacterial isolates Z7, Z9, and Z63.

\begin{tabular}{llll}
\hline Morphological characteristics & Z7 & Z9 & Z63 \\
\hline Staining & Gram positive & Gram positive & Gram negative \\
Arrangements & Rods In chains & Short rods & Short rods \\
Form & Circular & Circular & Irregular \\
Margin & Serrated & Sleek & Sleek \\
Growth level & Superficial & Raised & Raised \\
Catalase activity & + & + & + \\
Gelatin hydrolysis test & + & + & - \\
Starch hydrolysis test & + & + & - \\
Casein hydrolysis test & + & - & - \\
Xylanase activity & + & + & - \\
Urease activity & - & - & + \\
Lipase activity & - & - & + \\
Vogeus prasukauer reaction & - & - & - \\
Methyl red reaction & - & - & - \\
Anaerobic growth & - & - & +
\end{tabular}

\section{Identification of the three chosen bacterial isolates PCR product of 16s rRNA}

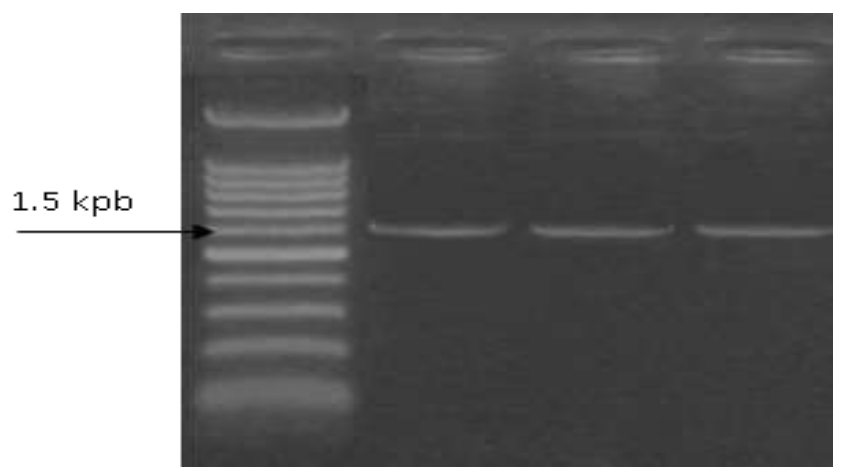

Fig (3) Agarose gel electrophoresis shows the PCR products of 16s rRNA of Bacillus cereus strain Z7, Bacillus licheniformis strain Z9 and Klebsiella oxytoca strain Z63.

The genomic DNA of the three bacterial colonies Z7, Z9, and Z63 were extracted. Genomic DNA which extracted from these bacteria was used to amplify $16 \mathrm{~S}$ rRNA gene. The PCR amplified products of approximately $1.5 \mathrm{~kb}$ were resolved on $1.2 \%$ agarose gel (Figure 3). Amplified PCR products were gel eluted and outsourced to (Macrogen, south Korea) for sequencing. The sequences obtained in Fasta format were analyzed using NCBI nucleotide BLAST tool and compared with the known NCBI database sequences. Analysis of 16S rRNA gene sequence of the three chosen strain
The obtained sequence of strains Z7, Z9 and Z63 was assembled, analyzed and submitted in the GenBank under the accession numbers of (KT693283), (KT693282), and (KT693284) respectively which revealed the maximum identity of these isolates and allowed identification of these cellulose-degrading bacterial strains (Table 2). The Phylogenetic tree computed using the $\mathrm{NJ}$ method revealed that the isolated Bacillus licheniformis strain Z9, Bacillus cereus strain Z7, and Klebsiella oxytoca strain Z63 were classified in clade with other strains of B. licheniformis, Bacillus cereus and Klebsiella oxytoca strains (Fig. 4). 
Table (2) Indicates the accession numbers of the 16s rRNA gene sequence for the three chosen strains.

\begin{tabular}{lll}
\hline No. & \multicolumn{1}{c}{ Name of the 16s rRNA sequence } & Accession no. \\
\hline 1 & Bacillus cereus strain Z7 16S rRNA gene, partial sequence & KT693283 \\
2 & Bacillus licheniformis strain Z9 16S rRNA gene, partial sequence & KT693282 \\
3 & Klebsiella oxytoca strain Z63 16S rRNA gene, partial sequence & KT693284 \\
\hline
\end{tabular}

Various cellulose-degrading bacteria have been found in different environments. Cellulase gene of Bacillus spp. has been reported by many researchers [15],[23], [27]. Poovazhagi [19] distinguished Bacillus subtilis
P15 strain by morphological, physiological, and biochemical portrayal and 16S rRNA from soil samples in screening for cellulases.
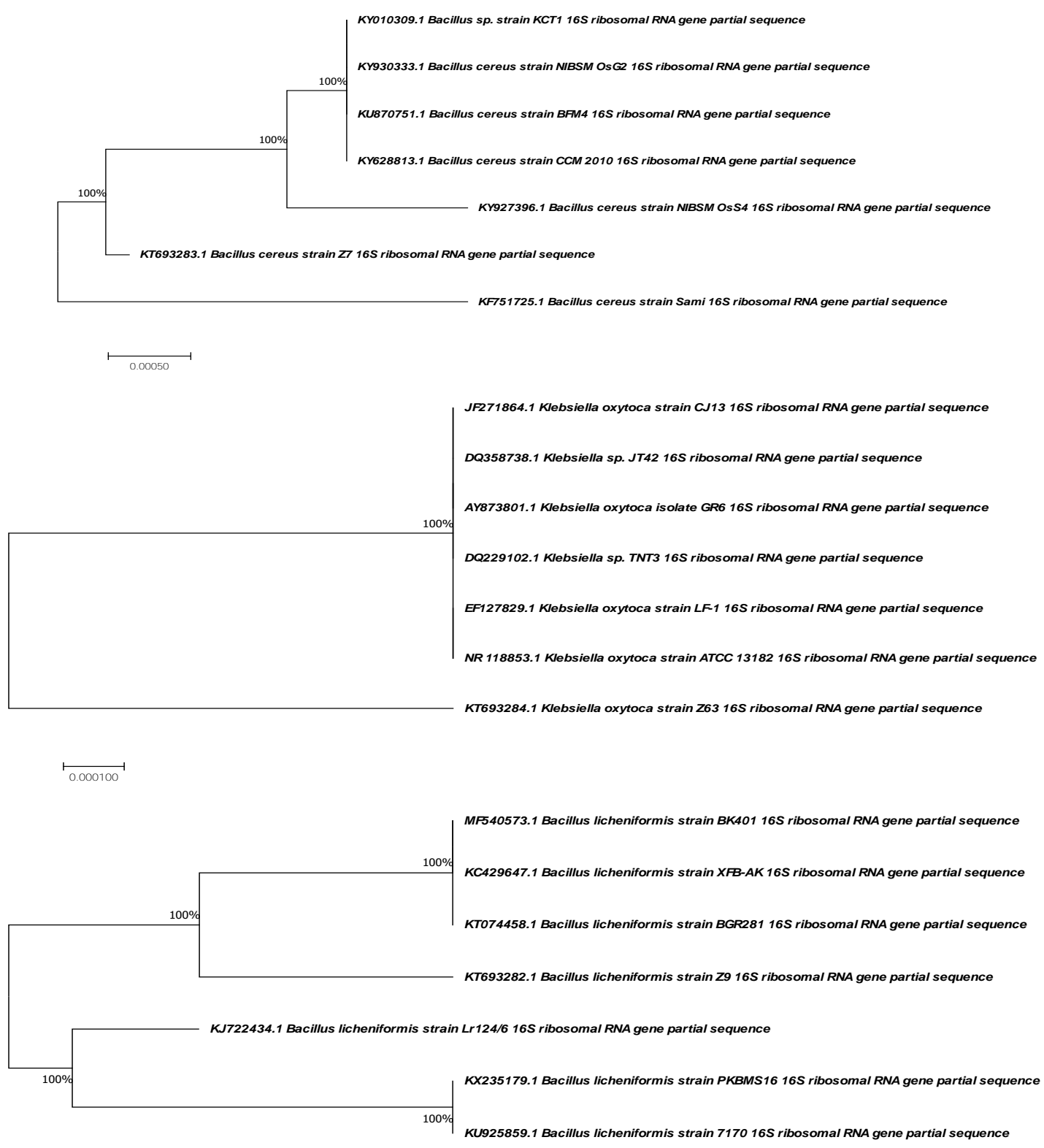

$\stackrel{\longmapsto .00020}{1}$

Fig. (4) Molecular phylogenetic analysis of Bacillus licheniformis strain Z9 Bacillus cereus strain Z7, and Klebsiella oxytoca strain Z63 with the neighbor joining methods using MEGA 7 software. The bars represent the distance values calculated by MEGA 7, and the values at the nodes represent the percentages of 1000 bootstrap replicates. 


\section{Conclusion}

For decades, many microbes able to hydrolyze cellulose into simple sugars were examined. Nevertheless, there were still need for newly identified cellulolytic bacteria. In this investigation we have isolated and discovered cellulase that produces soilbased bacteria. The bacterial isolates were characterised by morphological and biochemical testing and $16 \mathrm{~S}$ rRNA sequencing validated. They were identified as strain $\mathrm{Z7}$ of Bacillus cereus, strain Z9 of Bacillus licheniformis and strain Z63 of Klebsiella oxytoca. Cellulose generating bacteria may be insulated, screened and identified to give an excellent starting point for the discovery in the industrial and agricultural fields in Egypt of such helpful enzymes.

\section{References}

[1] A. Ashabil, K. Lutfiye, A. Burhan Alkaline thermostable and halophilic endoglucanase from Bacillus licheniformis C108. Afr J Biotechnol.vol. 10,pp.789-796,2011.

[2] MK. Bakare, IO. Adewale, A. Ajayi, OO. Shonukan Purufication and characterization of cellulase from the wild-type and two improved mutants of Pseudomonas fluorescens. Afri J Biotechnol.vol. 4,pp.898-9042005.

[3] BK. Bajaj, H. Pangotra, AM. Wani, P. Sharma, A .Sharma Partial purification and characterization of a highly thermostable and $\mathrm{pH}$ stable endoglucanase from a newly isolated Bacillus strain M-9. Indian $\mathbf{J}$ Chem Technol.vol. 16,pp.382-387,2009.

[4] D. Bergey, Manual of Determinative Bacteriology. American Society for Microbiology. Williams \& Willkins Co. Publishers, Baltimore, USA.vol. 1957,pp.VII Edition, 1957.

[5] KM. Bischoff, AP. Rooney, XL. Li, S. Liu, SR. Hughes Purification and characterization of a family 5 endoglucanase from a moderately thermophilic strain of Bacillus licheniformis. Biotechnol Lett .vol.28,pp.1761-1765,2006.

[6] PS .George, A .Ahmad, MB. Rao Studies on carboxymethyl cellulase produced by an alkalothermophilic actinomycete. Bioresource Technol.vol. 77,pp.171-175,2001.

[7] G. Immanuel, R .Dhanusha, P. Prema, A. Palavesam Effect of different growth parameters on endoglucanase enzyme activity by bacteria isolated from coir retting effluents of estuarine environment. Internat J Environmental Science and Technology.vol. 3,pp.25-34,2006.

[8] HJ .Kang, K .Uegaki, H. Fukada, K .Ishikawa Improvement of the enzymatic activity of the hyperthermophilic cellulase from Pyrococcus horikoshi. Extremophiles.vol. 11,pp.251256,2007.

[9] J. Kaur, BS. Chadha, BA. Kumar, HS. Saini Purification and characterization of two endoglucanases from Melanocarpus sp. MTCC 3922. Bioresour Technol.vol. 98,pp.74-81. ,2007.

[10] JY. Kim, SH .Hur, JH .Hong. Purification and characterization of an alkaline cellulase from a newly isolated alkalophilic Bacillus sp. HSH-810. Biotechnol Lett.vol. 27,pp.313-316,2005.

[11] RC. Kuhad, R.Gupta, A. SinghMicrobial cellulases and their industrial applications. Enzyme Res.vol.2011,pp.1-10, 2011.

[12] YL.Liang, Z. Zhang, M .Wu, et alIsolation, screening and identification of cellulolytic bacteria from natural reserves in the subtropical region of China and optimization of cellulase production by Paenibacillus terrae ME27-1. BioMed Res Int.vol.2014,pp.1-13,2014.

[13] S.A.S Mohamed, A.M.Y. Magdi, F.H. Francis, and A.N. Moustafa, Production of Cellulase in Low-Cost Medium by Bacillus subtilis KO Strain. World Applied Sciences Journal.vol. 8,pp.35-42,2010.

[14] G.Nikky, P.Ravi, K.V. Sumit, and C.S. Prakash, Purification and characterization of cellullase from Pseudouonas sp. Isolated from waste dumping site soil.Appl. Biotechnol Bio eng.vol. 6(3),pp.118-124,2019.

[15] K.Ozaki, , S.Shikata, , S. Kawai, S.Ito, K.Okamoto, Molecular cloning and nucleotide sequence of a gene for alkaline cellulase from Bacillus sp. KSM-635. Journal of General Microbiology.vol.136,pp. 1327-1 334,1990.

[16] K.K. Pandey, S. Mayilraj, T. Chakrabarti, Pseudomonas indica sp.Nov., a novel butane utilizing species. In International Journal of Systematic and Evolutionary Microbiology.vol. 52,pp. 1559-1567,2002.

[17] IB. Patagundi, CT. Shivasharan, BB. Kaliwal Isolation and characterization of cellulase producing bacteria from soil. Int J Curr Microbiol App Sci.vol.3,pp.59-69,2014.

[18] ZYH. Percival, ME. Himmel, JR. Mielenz Outlook for cellulase improvement: screening and selection strategies. Biotechnol Adv.vol.24(5),pp.452-481,2006.

[19] R. Poovazhagi, and K.R. Vijaya Isolation and Characterization of Alkaline cellulase by Bacillus subtilis P15 from soil. International Journal of Emerging Technologies and Innovative Research.vol.6, Issue 6,pp.304-311,2019.

[20] K.V.Reddy, T.V. Lakshmi, R. A.V. Krishna, V.H. Bindu, and M.L. Narasu, Isolation, Screening, Identification and optimized production of extracellular Cellulase from Bacillus subtilis Sub.sps using Cellulosic Waste as Carbon Source. International Journal of Current Microbiology and Applied Sciences.vol.5,pp.442-451,2016.

[21] S. Saha, R .Roy, SK. Sen, AK. Ray Characterization of cellulase-producing bacteria from the digestive tract of tilapia, Oreochromis mossambica (Peters) and grass carp, 
Ctenopharyngodon idella (Valenciennes). Aquaculture Research.vol. 37,pp.380-388,2006.

[22] JK, Saini, Arti, L. Tewari Simultaneous isolation and screening of cellulolytic bacteria: selection of efficient medium. J Pure App Microbiol.vol.6,pp.1339-1344,2012.

[23] J. Sánchez-Torres, P.Pérez, , R. I. Santamaría A cellulase gene from a new alkalophilic Bacillus sp. (strain N186-1). Its cloning, nucleotide sequence and expression in Escherichia coli. Applied microbiology and biotechnology.vol. 46,pp.149-155,1996.

[24] P .Saranraj, D. Stella, Reetha DMicrobial cellulases and its applications: a review. Int $\mathbf{J}$ Biochem Biotech Sci.vol.1,pp.1-12,2012.

[25] R. Sharada, G. Venkateswarlu, S. Venkateswar, et al. Applications of cellulasesreview. Int J Pharma Chem Biol Sci.vol.4,pp.424437,2014 .

[26] J.Singh, Production of Carboxymethyl Cellulase by Bacillus cereus JS1 Strain in LowCost Agriculture Waste Medium. Research Journal of Biotechnology.vol. 8,pp.11-20,2013.

[27] N.Sumitomo, , K.Ozaki, , S.Kawai, S. Ito, Nucleotide sequence of the gene for an alkaline endoglucanase from an alkalophilic Bacillus and its expression in Escherichia coli and Bacillus subtilis. Bioscience, Biotechnology, and Biochemistry.vol. 56, pp. 872-877,1992.

[28] R.M.Teather, , P. J.Wood, Use of Congo redpolysaccharide interactions in enumeration and characterization of cellulolytic bacteria from the bovine rumen. Applied and environmental microbiology.vol.43, pp. 777-780, 1982.

[29] LJ Yin, PS. Huang, Lin HH Isolation of cellulase-producing bacteria and characterization of the cellulase from the isolated bacterium Cellulomonas Sp. YJ5. J Agric Food Chem.vol. 58,pp.9833-9837,2010.

[30] YR .Yin, ZH. Meng, QW. Hu, et al. The hybrid strategy of Thermoactinospora rubra YIM $77501 \mathrm{~T}$ for utilizing cellulose as a carbon source at different temperatures. Front Microbiol.vol.8, pp.942, 2017. 